\title{
Evaluation of the effects of Prunus dulcis on mice models of depression
}

\author{
Gokullraj Kannan ${ }^{1}$, Ponnuswamy Kameswaran ${ }^{2 *}$
}

${ }^{1}$ Karpagam Faculty of Medical Sciences and Research, Coimbatore, Tamil Nadu, India ${ }^{2}$ Department of Pharmacology, Karpagam Faculty of Medical Sciences and Research, Coimbatore, Tamil Nadu, India

Received: 09 July 2019

Revised: 12 August 2019

Accepted: 16 August 2019

\section{*Correspondence to:}

Dr. Ponnuswamy Kameswaran, Email: p69kavi@yahoo.co.in

Copyright: (C) the author(s), publisher and licensee Medip Academy. This is an openaccess article distributed under the terms of the Creative Commons Attribution NonCommercial License, which permits unrestricted noncommercial use, distribution, and reproduction in any medium, provided the original work is properly cited.

\begin{abstract}
Background: Prunus dulcis (almond) contains high amounts of Inositol hexakisphosphate (IP6) which has proven antidepressant effects. Hence this study was done to evaluate the effects of Prunus dulcis on mice models of depression.

Methods: Tails suspension test (TST) and forced swim test (FST) are usually used to assess the antidepressant activity in animal models. They were employed to analyse the effectiveness of Prunus dulcis before and after two weeks of the study period and the results were compared. The animals were divided into 4 groups of 6 mice each.group-1 (Normal control); group-2 was given fluoxetine $10 \mathrm{mg} / \mathrm{kg}$; group- 3 and group- 4 were given $600 \mathrm{mg} / \mathrm{kg}$ and $1200 \mathrm{mg} / \mathrm{kg}$ of Prunus dulcis extract respectively. All the animals were on standard chow diet the entire duration of the study.

Results: Prunus dulcis (almond) is found to be effective in treating depression, by significantly reducing the immobility period on test group 1 in forced swim test $(\mathrm{p}<0.05)$ and test group 2 in tail suspension test $(\mathrm{p}<0.05)$.

Conclusions: The results clearly indicate the beneficial effects Prunus dulcis (almond) on mice models of depression. Further studies are required to prove its effectiveness in humans.
\end{abstract}

Keywords: Depression, Phosphoinositol hexakis phosphate, Antidepressant activity

\section{INTRODUCTION}

Depression is one of the commonest cause of disability which affects $16 \%$ of the world population. ${ }^{1}$ It has increasing attention, while the underlying mechanism of this disorder is not characterized. According to published reports from the World Health Organization (WHO), Depression is projected to be a major reason for disability in the world by $2030 .^{2}$ In the United States, about $10 \%$ of the population at any time is inflicted with depression. ${ }^{1}$

The cardinal symptoms of depression include depressed mood, anhedonia (decreased ability to experience pleasurable activity such as food, social interactions and sex), irritability, difficulty in concentrating, disturbed sleep, appetite and cognition and tendency for suicide. ${ }^{3}$
The "monoamine hypothesis" suggests that, a deficiency or imbalance in the monoamine neurotransmitters such as serotonin, norepinephrine and dopamine can lead to depression. This hypothesis is also supported by the fact that the known antidepressants like tricyclic antidepressants, selective serotonin reuptake inhibitors and monoamine oxidase inhibitors are known to boost monoamine function. ${ }^{4}$

Tryptophan is the aromatic amino acid precursor of 5hydroxytryptamine (Serotonin), which is a "monoamine" neurotransmitter in the brain. Tryptophan is metabolized by the enzyme tryptophan pyrrolase. It is known that xanthine oxidase is an endogenous activator of tryptophan pyrrolase enzyme which brings about 
increased degradation of tryptophan and reduces its level in the body thus contributing to depression. ${ }^{5}$

Allopurinol and febuxostat are potent xanthine oxidase inhibitors, primarily used in the treatment of hyperuricemia and gout. ${ }^{6}$ Since they inhibit xanthine oxidase, these drugs may have anti-depressant effect.

Inositols increase the level of tryptophan in the body by inhibiting xanthine oxidase enzyme. Previous studies state that inositols have antidepressant activity. ${ }^{7}$

Food sources rich in inositol are oil seeds and nuts. Prunus dulcis (almond) is known to have high phytic acid (inositol) content (0.35-9.42 g/100g). ${ }^{8}$ In addition, Prunus dulcis also has antioxidant property. Since it is a natural product, there are no significant side effects. It is also a commonly consumed nut. So, Prunus dulcis which is rich in Inositol hexakisphosphate (phytic acid) is used in this study.

This is the first study to evaluate the effect of phytic acid rich Prunus dulcis on mouse models of depression. If Prunus dulcis (almond) is found to have beneficial effects on depression, it could be used in addition to existing antidepressant drugs. The dose of antidepressant drugs can be reduced when they can be used along with Prunus dulcis in treatment for major depressive disorder thus vastly reducing the side effects of antidepressant drugs.

\section{Objective}

The objective of the study was to evaluate the effect of Prunus dulcis on mouse models of depression.

\section{METHODS}

The study was initiated after getting approval from the Institutional Animal Ethics Committee. Twenty-four Swiss Albino mice weighing 25 to 30 gms were procured from the central animal house of Karpagam University for the study. The animals were housed in standard cages in the Animal House, Karpagam Faculty Of Medical Sciences and Research for acclimatization under controlled temperature around $25^{\circ} \mathrm{C}$ and 12 hours lightdark cycles.

They were supplied with a standard chow diet and water ad libitum.

\section{Drugs used}

- Fluoxetine $(10 \mathrm{mg} / \mathrm{kg})$

- Nuts of Prunus dulcis (Almonds) was purchased from the local market. Two doses $600 \mathrm{mg} / \mathrm{kg}, 1200 \mathrm{mg} / \mathrm{kg}$ was used in the study.

Aqueous extract of the Prunus dulcis was prepared by using soxhlet apparatus and used for the study. ${ }^{9}$

\section{Experimental design}

24 mice were divided into 4 groups consisting of

- $\quad$ Group I $(\mathrm{N}=6)$ : normal control

- Group II ( $\mathrm{N=6})$ : standard control -fluoxetine 10 $\mathrm{mg} / \mathrm{kg}$.

- Group III (N=6): test group 1- Prunus dulcis 600 $\mathrm{mg} / \mathrm{kg}$

- Group IV (N=6): test group 2- Prunus dulcis 1200 $\mathrm{mg} / \mathrm{kg}$.

All the drugs were given orally via mice feeding tube for a period of 2 weeks.

\section{Parameters used}

\section{Forced swim test}

The forced swim test is a behavioural test used for evaluation of antidepressant drugs, antidepressant efficacy of new compounds, and experimental manipulations that are aimed at rendering or preventing depressive-like states. Mice are placed in an inescapable transparent tank that is filled with water and their escape related mobility behaviour is measured. The forced swim test is straightforward to conduct, reliable and it requires minimal specialized equipment.

There is one session which is 6 min long, divided into pretest (the first $2 \mathrm{~min}$ ) and test (the last $4 \mathrm{~min}$ ).

- Inorder for the mice to get acclimatized to the testing environment, they were transported in their home cages $30 \mathrm{~min}$ prior to behavioural testing to the waiting room.

- The cylinders $(30 \mathrm{~cm}$ high $\times 20 \mathrm{~cm}$ diameter $)$ were filled with tap water at $25{ }^{\circ} \mathrm{C}$ and the depth of water was adjusted according to the mouse' size, so that it cannot touch the bottom of the container with its hind legs. ${ }^{10}$

Before and after 14 days of drug administration, forced swim test (FST) were done for all groups to assess the pre and post drug effect. The mice were placed in the water, based on it's activity, the actions of the mice were noted as swimming/struggling/immobile. The time in which the mouse was immobile was noted for all the 4 groups. Animal with no struggle and making only slightest movements of it's limbs were considered to be immobile.

\section{Tail suspension test}

The tail-suspension test is done as a mouse behavioural test useful in the screening of potential antidepressant drugs and assessing of other manipulations that are expected to affect depression related behaviours. Mice are suspended by their tails with tape, in such a position that it cannot escape or hold on to nearby surfaces. 
During this test, typically six minutes in duration, the resulting escape-oriented behaviours were quantified. ${ }^{11}$

Before and after 14 days of drug administration, TST was done for all groups to assess the pre and post drug effect.

The time in which the mouse was immobile was noted for all the 4 groups. Mice were considered immobile when they hang passively and are completely motionless.

\section{Statistical analysis}

One-way ANOVA was used to assess the results. Student's t test was done to analyse the results between the groups and results are expressed in mean \pm standard deviation and regarded significant if $\mathrm{p}<0.05$.

\section{RESULTS}

\section{Effect on immobility in FST}

In this study, the effect of Prunus dulcis on mice models of depression was evaluated with the help of FST. The duration of immobility was recorded and was compared with that of normal control \& standard control.

The mice in the normal control group showed an immobility time of $68 \pm 4.89$ seconds.

Duration of immobility of mice treated with fluoxetine was $50.8 \pm 10$ seconds.

The duration of immobility of mice treated with Prunus dulcis $600 \mathrm{mg} / \mathrm{kg}$ was $33 \pm 8.24$ and those with 1200 $\mathrm{mg} / \mathrm{kg}$ was $44 \pm 14.3$.

Table 1: Represents immobility time in FST.

\begin{tabular}{lllll|}
\hline No. & Group & Dose & $\begin{array}{l}\text { No. of } \\
\text { animals }\end{array}$ & $\begin{array}{l}\text { Immobility } \\
\text { time }\end{array}$ \\
\hline $\mathbf{1}$ & $\begin{array}{l}\text { Normal } \\
\text { control }\end{array}$ & - & 6 & $68 \pm 4.89$ \\
\hline $\mathbf{2}$ & $\begin{array}{l}\text { Standard } \\
\text { control }\end{array}$ & $10 \mathrm{mg} / \mathrm{kg}$ & 6 & $50.8 \pm 10$ \\
\hline $\mathbf{3}$ & Test -1 & $600 \mathrm{mg} / \mathrm{kg}$ & 6 & $33 \pm 8.24 * *$ \\
\hline $\mathbf{4}$ & Test -2 & $1200 \mathrm{mg} / \mathrm{kg}$ & 6 & $44 \pm 14.3$ \\
\hline$* \mathrm{p}<0.05 * * \mathrm{p}<0.01 * * * \mathrm{p}<0.001$. & & \\
$\mathrm{P} \quad$ value was significant $(\mathrm{p}<0.01)$ & between Standard \\
control and test group 1.
\end{tabular}

Fluoxetine, which is the positive control, significantly reduced the immobility time in the FST as compared to control when administered for 14 consecutive days. Prunus dulcis was given as an aqueous extract, both 600 $\mathrm{mg} / \mathrm{kg}$ as well as $1200 \mathrm{mg} / \mathrm{kg}$ showed significant reduction in immobility period compared to standard control.

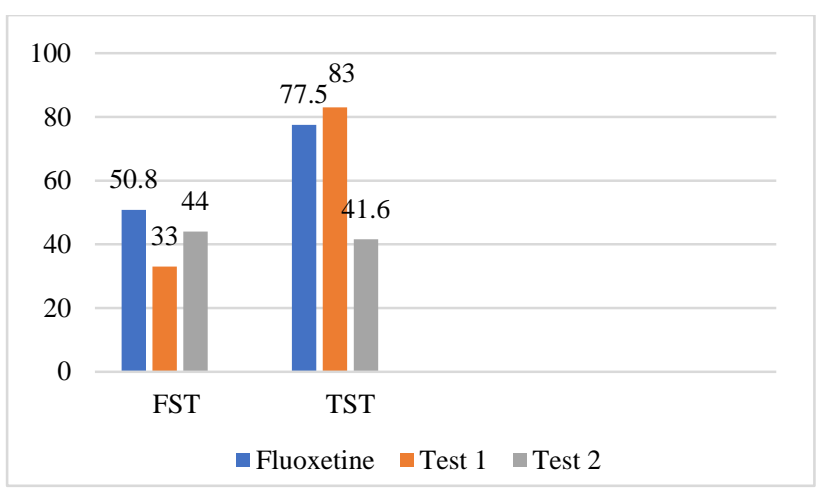

Figure 1: Comparison of immobility periods in FST and TST among the 3 groups.

Y axis-immobility period (seconds).

\section{Effect on immobility in TST}

The effect of Prunus dulcis on mice models of depression was evaluated using tail suspension test. The immobility period was recorded for all 4 groups and compared.

The mice in normal control group showed an immobility period of $73 \pm 4.76$ seconds.

Duration of immobility in standard control group was $77.5 \pm 8.40$ seconds.

The duration of immobility of mice treated with Prunus dulcis $600 \mathrm{mg} / \mathrm{kg}$ was $83.66 \pm 10.74$ and those with 1200 $\mathrm{mg} / \mathrm{kg}$ was $41.66 \pm 7.22$ seconds respectively.

The Prunus dulcis $1200 \mathrm{mg} / \mathrm{kg}$ which was given as an aqueous extract showed significant reduction $(\mathrm{p}<0.001)$ in immobility period compared to standard control.

\section{DISCUSSION}

The forced swim test is the most commonly used behavioural model of depression in animals. This test is quite sensitive and relatively specific to all major classes of anti-depressant drugs. It is widely employed in rodents to predict anti-depressant potential of drugs. ${ }^{10}$

In forced swim test, the test group 1 which was given Prunus dulcis $600 \mathrm{mg} / \mathrm{kg}$ in aqueous extract form was found to significantly reduce the immobility period compared to fluoxetine $10 \mathrm{mg} / \mathrm{kg}$.

The test group 2 showed a reduction in the immobility period but the results were not significant when compared to standard control.

The tail-suspension test (TST) is done as a mouse behavioural test useful in the screening of potential antidepressant drugs and assessing of other manipulations that are expected to affect depression related behaviours. 
In tail-suspension test, both test group 1 as well as test group 2 were found to reduce the period of immobility but The test group 2 in which $1200 \mathrm{mg} / \mathrm{kg}$ Prunus dulcis in aqueous extract form used, produced significant reduction in the immobility period as shown in Table 2.

The effect of Prunus dulcis in weight of the mice were shown in Table 3. There appears to be significant $(\mathrm{p}<0.05)$ reduction in the weight of the mice.

The results obtained in this study were comparable with the study done by Karve et al, in the use of allopurinol and febuxostat in mice models of depression.

Studies also reveal that Prunus amygdalus dulcis (sweet almonds) were found to have anxiolytic property. ${ }^{12}$

Table 2: Represents results of tail suspension test.

\begin{tabular}{|lllll|}
\hline No. Group & Dose & $\begin{array}{l}\text { No. of } \\
\text { animals } \\
\text { used }\end{array}$ & $\begin{array}{l}\text { Immobility } \\
\text { time }\end{array}$ \\
\hline $\mathbf{1}$ & $\begin{array}{l}\text { Normal } \\
\text { control }\end{array}$ & - & 6 & $73.3 \pm 4.76$ \\
\hline $\mathbf{2}$ & $\begin{array}{l}\text { Standard } \\
\text { control }\end{array}$ & $10 \mathrm{mg} / \mathrm{kg}$ & 6 & $77.5 \pm 8.40$ \\
\hline $\mathbf{3}$ & Test-1 & $600 \mathrm{mg} / \mathrm{kg}$ & 6 & $83.66 \pm 10.74$ \\
\hline $\mathbf{4}$ & Test-2 & $1200 \mathrm{mg} / \mathrm{kg}$ & 6 & $41.66 \pm 7.22 * * *$ \\
\hline$* \mathrm{p}<0.05 * * \mathrm{p}<0.01 ; * * * \mathrm{p}<0.001$. & & \\
\hline
\end{tabular}

Table 3: The results from the FST and TST of the three groups are compared in this table.

\begin{tabular}{|lll|}
\hline & Mean \pm SD & Mean \pm SD \\
\hline Preparations & $\begin{array}{l}\text { Forced swim } \\
\text { test immobility } \\
\text { period(s) }\end{array}$ & $\begin{array}{l}\text { Tail suspension } \\
\text { test immobility } \\
\text { period (s) }\end{array}$ \\
\hline $\begin{array}{l}\text { Fluoxetine (10 } \\
\text { mg/kg) }\end{array}$ & $50.8 \pm 10$ & $77.5 \pm 4.76$ \\
\hline $\begin{array}{l}\text { Prunus dulcis }(600 \\
\text { mg/kg) }\end{array}$ & $33 \pm 8.24$ & $83.66 \pm 10.74$ \\
\hline $\begin{array}{l}\text { Prunus dulcis } \\
(\mathbf{1 2 0 0} \text { mg/kg) }\end{array}$ & $44 \pm 14.3$ & $41.66 \pm 7.22$ \\
\hline
\end{tabular}

$* \mathrm{p}<0.05 ; * * \mathrm{p}<0.01 ; * * * \mathrm{p}<0.001$.

\section{CONCLUSION}

The results indicate that Prunus dulcis (almond) has antidepressant effect and it also produced significant weight loss in mouse models.

Further studies are needed to confirm the antidepressant effect of Prunus dulcis in humans.

\section{ACKNOWLEDGEMENTS}

The authors gratefully acknowledge the support of ICMRSTS.

\section{Funding: ICMR}

Conflict of interest: None declared

Ethical approval: The study was approved by Institutional Animal Ethical Committee IAEC NO KFMSR/STP/O1/18

\section{REFERENCES}

1. Kessler RC, Berglund P, Demler O, Jin R, Koretz D, Merikangas KR, et al. National Comorbidity Survey, $\mathrm{R}$. The epidemiology of major depressive disorder: results from the National Comorbidity Survey Replication (NCS-R). JAMA. 2003;289(23):3095105.

2. Mathers C, Boerma T, Fat DM. The global Burden of Diesease: 2004. update. 2008.

3. Nestler EJ, Barrot M, DiLeone RJ, Eisch AJ, Gold SJ, Monteggia LM. Neurobiology of depression. Neuron. 2002;34(1):13-25.

4. Lee S, Jeong J, Kwak Y, Park SK. Depression research: Where are we now? Mol Brain. 2010;3:8.

5. Becking GC, Johnson WJ. The inhibition of tryptophan pyrrolase by allopurinol, an inhibitor of xanthine oxidase. Can J Biochem. 1967;45:1667-72.

6. Rundles RW. The development of allopurinol. Arch Intern Med. 1985;145:1492-503.

7. Chengappa KN, Levine J, Gershon S, Mallinger AG, Hardan A, Vagnucci A, et al. Inositol as an add-on treatment for bipolar depression. Bipolar Disord. 2000;2:47-55.

8. Schlemmer U, Frølich W, Prieto RM, Grases F. Phytate in foods and significance for humans: Food sources, intake, processing, bioavailability, protective role and analysis. Mol Nutr Food Res. 2009;53:33075 .

9. Luque de Castro MD, García-Ayuso LE. Soxhlet extraction of solid materials: an outdated technique with a promising innovative future. Analytica Chimica Acta. 1998;369(1-2):1-10.

10. Porsolt RD, Bertin A, Jalfre M. Behavioural Despair in Mice: A Primary Screening Test for Antidepressants. Archives Internationales de Pharmacodynamie et de Therapie. 1977;229:327-30.

11. Steru L, Chermat R, Thierry B, Simon P. The Tail Suspension Test: A New Method for Screening Antidepressants in Mice. Psychopharmacology. 1985;85(3):367-70.

12. Sahib ZH. Assessment of Anxiolytic Activity of Nuts of Prunus Amygdalus Dulcis (Almond) in Mice. Medical J Babylon. 2014.

Cite this article as: Kannan $\mathrm{G}$, Kameswaran $\mathrm{P}$. Evaluation of the effects of Prunus dulcis on mice models of depression. Int J Basic Clin Pharmacol 2019;8:2126-9. 